\title{
The Frequency of Malnutrition in Patients with Type 2 Diabetes
}

\section{Tip 2 Diyabet Hastalarında Malnütrisyon Sıklı̆̆ı}

\author{
Mirac VURAL KESKINLER ๑, Güneș FEYIZOGLU $\odot$, Kubra YILDIZ ๑, Aytekin OGUZ ๑
}

Ethics Committee Approval: This study was approved by Istanbul Medeniyet University Göztepe Educational and Research Hospital Ethics Committee, 06 March 2018, 2018/0074.

Conflict of interest: The authors declare that they have no conflict of interest.

Funding: None.

Informed Consent: Informed consents were taken from the participants of the study.
Cite as: Vural Keskinler M, Feyizoglu G, Yildiz K, Oguz A. The frequency of malnutrition in patients with type 2 diabetes. Medeni Med J. 2021;36:117-22.

\begin{abstract}
Objective: Obesity is one of the most common comorbidities of diabetes mellitus (DM) whose frequency is rapidly increasing nowadays. Although obesity caused by excessive and unbalanced nutrition often accompanies diabetes; malnutrition is another complication of diabetes. This study was conducted to investigate the frequency of malnutrition in individuals with diabetes.

Method: This study is a cross-sectional study. The patients with type 2 diabetes followed up in the diabetes outpatient clinic of a university hospital between February and March 2018 were included in the study. Anthropometric measurements of the patients and "Nutritional Risk Screening-2002" (NRS-2002) scores were recorded.

Results: A total of 222 (F:132 59.4\%) patients were included in the study. When two groups with higher NRS ( $\geq 3)$ and lower NRS (<3) scores less than 3 were compared, any significant difference was not detected between two groups in terms of age, waist circumference and $H b A 1 c$ values. Only BMI was found to be lower in the group with malnutrition risk (p:0.030). When the patients were evaluated in terms of diabetes treatments and risk of malnutrition, any significant intergroup difference was not found ( $p: 0.847$ ).

Conclusion: It was found that there is a risk of malnutrition in one of every seven diabetics with a high body mass index who were being followed up in the diabetes outpatient clinic.
\end{abstract}

Keywords: Diabetes mellitus, malnutrition, nutritional requirement

öz

Amac: Günümüzde sıklı̆ğ hızla artmakta olan diabetes mellitusun (DM) en sık komorbiditelerinden biri obezitedir. Aşırı ve dengesiz beslenmenin yol açtı̆̆ı obezite, sıklıkla diyabete eşlik etse de; malnütrisyon da diyabetin bir diğer komplikasyonu olarak karşımıza çıkmaktadır. Bu çalışma diyabetli bireylerdeki malnütrisyon riski sıklığının incelenmesi amacıyla yapılmıştır.

Yöntem: Bu çalıșma kesitsel bir çalıșmadır. Subat 2018 - Mart 2018 tarihleri arasında bir üniversite hastanesinin diyabet polikliniğinde takip edilen tip 2 diyabetli hastalar çalışmaya dahil edildi. Hastaların antropometrik ölçümleri ve "Nutritional Risk Screening-2002" (NRS-2002) skorları kayıt altına alınmıştır.

Bulgular: Calışmaya 222 (Kadın: 132, \%59,4) hasta alındı. NRS skoru yüksek (NRS $\geq 3$ ) olan ve $(N R S<3)$ olan iki grup karşılaştırıldığında, yaş, bel çevresi ve HbA1c açısından iki grup arasında da anlamlı bir fark yoktu. Malnütrisyon riski olan grupta sadece BKi daha düš̈u bulundu $(p=0.030)$. Hastalar diyabet tedavileri ve malnütrisyon riski açısından değerlendirildiğinde tedavi ve malnütrisyon riski açısından fark saptanmadı $(p=0.847)$.

Sonuç: Yapılan çalışmada diyabet polikliniğinde takip edilmekte olan ve beden kütle indeksi yüksek olan her yedi diyabetliden birinde malnütrisyon riskinin mevcut olduğu görülmüştür.

Anahtar kelimeler: Diyabet, malnutrisyon, nutrisyon gereksinimi
Received: 22 January 2021

Accepted: 4 May 2021

Online First: 18 June 2021

Corresponding Author:

M. Vural Keskinler

ORCID: 0000-0003-4863-9666

Istanbul Medeniyet University,

Department of Internal Medicine, Istanbul, Turkey

miracvural@hotmail.com

G. Feyizoglu

ORCID: 0000-0002-8005-1793

A. Oguz

ORCID: 0000-0002-2595-5167

Istanbul Medeniyet University,

Department of Internal Medicine, Istanbul, Turkey

K. Yildiz

ORCID: 0000-0002-4485-6244

Istanbul Medeniyet University,

Department of Nutrition and

Dietetics

Istanbul, Turkey 


\section{INTRODUCTION}

One of the most common comorbidities of DM, whose frequency is increasing rapidly today, is obesity. Although obesity is caused by excessive and unbalanced nutrition often accompanies diabetes; malnutrition is also another complication of diabetes. The American Society for Parenteral and Enteral Nutrition (ASPEN) refers people having two or more of the following symptoms such as insufficient energy intake, weight loss, muscle loss, subcutaneous fat tissue loss, regional or widespread fluid accumulation, and decreased hand grip strength, as malnutrition ${ }^{1}$.

Many studies were conducted investigating the coexistence of these two conditions. In a study conducted in hospitalized patients in Spain, it was shown that the risk of malnutrition is 1.4 times higher in people with diabetes ${ }^{2}$. In another study, malnutrition rate was observed as $21.2 \%$ in geriatric patients with diabetes, regardless of $\mathrm{BMI}^{3}$.

In a study conducted at Hacettepe University in Turkey, it was found that $28 \%$ of the patients who admitted to the geriatric outpatient clinic had poor nutritional status, while the malnutrition risk was $69 \%$ and the malnutrition rate was $12 \%$ in hospitalized patients ${ }^{4}$. In a study conducted at Istanbul University, malnutrition risk was $31 \%$ and malnutrition rate was $13 \%$ in patients who were admitted to the outpatient clinic, whereas malnutrition risk was determined as $39 \%$ and malnutrition rate as $25 \%$ in hospitalized patients $^{5,6}$. In another study, it was found that malnutrition is a common nutritional problem in older outpatient adults ${ }^{7}$. In a study conducted in Turkey, it was reported that the prevalence of malnutrition increases especially with age, making management of diabetes difficult ${ }^{8}$. The aim of the study is to determine the prevalence of malnutrition in patients admitted to diabetes outpatient clinic.

\section{MATERIAL and METHOD}

This study is a cross-sectional study. The patients with type 2 diabetes who were followed up in the diabetes outpatient clinic of a university hospital between February and March in 2018 were included in the study. Patients with type 1 diabetes, patients presenting with any disease that impairs nutritional status such as malignancy and pregnancy were not included in the study. Before conducting the study, all patients were informed about the study and only patients who volunteered to participate were included in the study. Anthropometric measurements (age, height, weight, and waist circumference), medications used and laboratory data (HbA1c) of the patients were recorded. Malnutrition screening of the patients was performed using Nutritional Risk Screening-2002 Test (NRS-2002), and their scores were recorded and analyzed?. According to the NRS-2002 screening test, patients with scores $\geq 3$ were considered to be at risk of malnutrition, and those with NRS scores of $<3$ were considered individuals without malnutrition risk. IBM SPSS 22.0 was used for the analysis of the data and the "Independent Samples Student $t$ test" was used for the analysis of independent and normally distributed variables (the correlation between NRS scores and BMI). Additionally, Mann-Whitney $U$ test was used to analyze the non-normally distributed independent variables (the correlation between NRS scores and age, waist circumference). Chi-square test was used to compare categorical variables (the correlation between gender and HbA1c, of NRS scores, educational, and employment status). Pearson correlation test was used to determine the relationship between quantitative variables (correlation between NRS scores and age, HbA1c, tobacco and alcohol consumption).

\section{RESULTS}

A total of 222 (132 females, 59.4\%) type 2 diabetics with a mean age of $58.1 \pm 10.0$ years 
were included in the study. The mean Body Mass Index (BMI) $\left(32.3 \pm 6.4 \mathrm{~kg} / \mathrm{m}^{2}\right)$, waist circumference $(105.4 \pm 12.2 \mathrm{~cm})$, and $\mathrm{HbA} 1 \mathrm{c}$ value $(8.1 \pm 1.8 \%)$ were noted Twenty-two (9.9\%) patients were illiterate, while others were primary school ( $n=160: 61.3 \%)$, high school $(n=40$ : $18.2 \%)$, and university ( $\mathrm{n}=24: 10.8 \%)$ graduates. Sixty-two (27.9\%) patients were employed, and $160(72.1 \%)$ patients were unemployed. Fifty-two (23.4\%) patients were smokers and six (2.7\%) patients were alcohol addict. One hundred and twenty-two (55.9\%) patients had hypertension, while others had hyperlipidemia ( $n=130 ; 58.6 \%)$, and chronic diseases such as asthma, coronary heart disease, COPD, depression, psoriasis, and gastritis ( $n=26: 11.7 \%)$. When the diabetes treatments of the patients were examined, the patients were using an oral antidiabetic $(n=124$ : 55.9\%), insulin ( $n=33: 14.9 \%)$, and both an oral antidiabetic, and insulin ( $\mathrm{n}=65: 29.3 \%)$.

Thirty-two (14.4\%) patients with a mean age of $62 \pm 11$ years including 20 (62.5\%) females, and 12 $(37.5 \%)$ males were at risk of malnutrition. Mean
BMI $\left(29.3 \pm 4.70 \mathrm{~kg} / \mathrm{m}^{2}\right)$, waist circumference $(101.8 \pm 10.04 \mathrm{~cm}), \mathrm{HbA} 1 \mathrm{c}$ values $(8.1 \pm 2.1 \%)$ of the patients were as indicated.

When the patients were evaluated in terms of diabetes treatments and risk of malnutrition, no significant intergroup difference was found in terms of treatment and malnutrition risk $(p=0.847)$.

There was no significant correlation between gender, age and $\mathrm{HbA} 1 \mathrm{c}(\mathrm{p}=0.507 \mathrm{r}=-0.045$, $\mathrm{p}=0.055 \mathrm{r}=1.129, \mathrm{p}=0.516$ and $\mathrm{r}=-0.052$, respectively) with NRS. It was observed that the NRS scores increased significantly with the decrease in BMI values and waist circumference ( $p<0.001$, and $p=0.002$, respectively). The analysis was repeated stratified based on gender and age. The risk of malnutrition was found to be higher in patients older than 65 years compared to those who were not $(p=0.007)$. It was found that having malnutrition risk does not differ by gender.

It was observed that the NRS scores did not

Table 1. Comparison of patients' NRS scores.

\begin{tabular}{|c|c|c|c|}
\hline & $\begin{array}{l}\text { NRS } \geq 3 \\
n=32(14.41 \%) \\
\text { n (\%) } \\
(\text { Mean } \pm \text { SD) (min-max) }\end{array}$ & $\begin{array}{l}\text { NRS }<3 \\
\text { n=190 (85.59\%) } \\
\text { n (\%) } \\
(\text { Mean+SD) (min-max) }\end{array}$ & $\mathbf{p}$ \\
\hline Female & $20(62.5)$ & $112(58.9)$ & 0.705 \\
\hline Male & $12(37.5)$ & $78(41.1)$ & 0.11 \\
\hline Age (year) & $62.62 \pm 10.88(43-85)$ & $57.36 \pm 9.77(27-82)$ & $0.030^{*}$ \\
\hline BMI $\left(\mathrm{kg} / \mathrm{m}^{2}\right)$ & $29.37 \pm 4.7(21.15-40.51)$ & $32.88 \pm 6.65(22.10-55.85)$ & 0.760 \\
\hline Waist circumference $(\mathrm{cm})$ & $101.81 \pm 10.04(88-121)$ & $106.03 \pm 12.46(80-140)$ & 0.764 \\
\hline $\mathrm{HbA} 1 \mathrm{c}(\%)$ & $8.14 \pm 2.11(6-14)$ & $8.12 \pm 1.81(5-15)$ & \\
\hline Education & & & $0.026^{*}$ \\
\hline Untutored & $6(18.8)$ & $16(8.4)$ & \\
\hline Primary school graduate & $24(75.0)$ & $112(58.9)$ & \\
\hline High school graduate & $2(6.3)$ & $38(20.0)$ & \\
\hline University graduate & 0 & $24(12.6)$ & 0.165 \\
\hline Smoking; n (\%) & $4(12.5)$ & $48(25.3)$ & 0.497 \\
\hline Alcohol use; n (\%) & 0 & $6(3.2)$ & $0.018^{*}$ \\
\hline Hypertension; n (\%) & $24(75.0)$ & $100(52.6)$ & $0.005^{*}$ \\
\hline Dyslipidemia; n (\%) & $26(81.3)$ & $104(54.7)$ & 0.07 \\
\hline $\begin{array}{l}\text { Comorbidities; n (\%) (Asthma, CAD, } \\
\text { COPD, Depression, Psoriasis, Gastritis) }\end{array}$ & $4(12.5)$ & $22(11.6)$ & \\
\hline
\end{tabular}

$B M I$, body mass index; $C A D$, coronary artery disease; COPD, chronic obstructive pulmonary disease Mann-Whitney U Test, Chi-Square Test, * $p<0,05$, statistically significant. 
decrease significantly with increasing education level $(p=0.029)$. NRS score was not significantly higher in unemployed patients $(p=0.029)$. There was no significant correlation between the use of tobacco and alcohol and NRS scores $(p=0.381$, $p=0.150$, respectively). It was observed that the relationship between the presence of comorbidities like hypertension and hyperlipidemia with NRS score was significant $(p=0.030, p=0.005$, respectively).

When the patients at risk or without risk of malnutrition were compared according to NRS scores, age, waist circumference, HbA1c values, educational status, smoking, alcohol, hypertension, dyslipidemia, comorbid conditions were not different between two groups. On the other hand, body mass index was higher in nonmalnourished group. Comparisons according to NRS scores are shown in Table 1.

\section{DISCUSSION}

In this study, it was observed that there was a risk of malnutrition in one of every seven type 2 diabetic patients followed up in diabetes outpatient clinics. It is often overlooked that some patients with type 2 diabetes, whose main problem is known to be overnutrition and positive energy balance, also have a significant risk of malnutrition. In a study conducted on hospitalized diabetes patients, 29\% of patients with type 2 diabetes were found to have malnutrition or increased risk of malnutrition. In that study, $72 \%$ of the patients were overweight or obese ${ }^{10}$. Considering the above-mentioned study, although the general physical condition of the patients in our study was good enough to allow outpatient control. All patients were overweight or obese, and $14 \%$ of them had a high malnutrition risk score, which makes our results even more striking. Although mean BMI values of patients in both arms of our study group were above the normal reference range, mean BMI was lower in patients with malnutrition risk when compared to the patients without.
Non-insulin dependent diabetes, which is overnutrition in its pathophysiology, is actually both result and cause of a type of malnutrition. Even if every individual who does not have sufficient and balanced diet intakes the required energy, if the patient does not consume the appropriate macro and micronutrients, then he/ she is considered to be a malnourished individual. In addition, complications of diabetes, diabetic gastroparesis also result in malnutrition ${ }^{11}$. In addition to diabetes comorbidity and treatment plan, patients are at risk of malnutrition as a result of changes in their dietary habits, restricted mobilization, socioeconomic differences and social isolation ${ }^{12,13}$. There are many factors that can increase the risk of malnutrition in patients with diabetes. First of all, diabetic autonomic neuropathy may cause nutritional disorders by affecting the gastrointestinal system. Metformin and GLP-1 agonists, which are antidiabetic drugs, may contribute to malnutrition together with their side effects on the gastrointestinal system. Chronic kidney disease that may develop due to diabetes is also a well-known reason of malnutrition ${ }^{14}$.

In the geriatric population, it is known that conditions such as decreased appetite, dietary restrictions, loneliness, and depression lead to malnutrition ${ }^{15}$. In the analysis performed on more than 10.000 elder people, it was reported that $20 \%$ of hospitalized patients and $4 \%$ of people receiving home care services were reported to have malnutrition ${ }^{16}$. Malnutrition rates are even higher in elderly and hospitalized patients with diabetes. In a study including 2329 geriatric patients hospitalized in Belgium, malnutrition was detected in $31 \%$ of the diabetic patients ${ }^{17}$. Although nutritional evaluation studies conducted with outpatients are rarely cited in the literature, in a study conducted by İlker Taşci et al. ${ }^{7}$ in our country, undernutrition was more common among older patients with type 2 diabetes.

NRS scores of our patients with lower education 
levels were higher than those with higher education levels. It is clear from studies that low education status is an important risk factor for many diseases ${ }^{18}$. It is impressive that the low education level of the Prospective Urban Rural Epidemiology (PURE) study is in the top three leading reasons of cardiovascular disease and death ${ }^{19}$.

The frequency of hypertension and hyperlipidemia was higher in the group with high malnutrition risk. The presence of hypertension and hyperlipidemia in diabetic patients increases the microvascular and macrovascular risks exponentially ${ }^{20}$. In addition to minimizing macrovascular complications and mortality due to diabetes, it was shown that all microvascular complications including autonomic neuropathy, which we mentioned above as factors that may increase the risk of malnutrition, were reduced by approximately $50 \%$ with multifactorial approach $^{21}$.

Our study also had some limitations. There was no detailed data on nutritional characteristics, and diabetic complications of the patients that can be associated with the risk of malnutrition. Our patient group were not a sample of all diabetic patients but consist of patients admitted to the outpatient clinic. However, we think that our results reflect the malnutrition status of diabetic patients who admitted in health institutions relatively well, thanks to the fact that patients were not subject to a mandatory referral chain according to our health system and that this study was conducted in an easily accessible outpatient clinics of a central hospital. However, since this screening tool (NRS) was not validated in our country when we conducted our research, we could not use this screening test ${ }^{22}$.

\section{CONCLUSION}

The risk of malnutrition in patients with diabetes should not be ignored, and it should be kept in mind that these two clinical conditions, which seem to be the contrary, may accompany each other.

\section{REFERENCES}

1. Stumvoll M, Goldstein BJ, Van Haeften TW. Type 2 diabetes: principles of pathogenesis and therapy. Lancet. 2005;365:1333-46. [CrossRef]

2. White JV, Guenter P, Jensen G, et al. Consensus statement: Academy of Nutrition and Dietetics and American Society for Parenteral and Enteral Nutrition: characteristics recommended for the identification and documentation of adult malnutrition (undernutrition). JPEN J Parenter Enteral Nutr. 2012;36:275-83. [CrossRef]

3. Sanz París A, García JM, Gómez-Candela C, et al. Malnutrition prevalence in hospitalized elderly diabetic patients. Nutr Hosp. 2013;28:592-9. [CrossRef]

4. Ülger Z, Halil M, Kalan I, et al. Comprehensive assessment of malnutrition risk and related factors in a large group of community-dwelling older adults. Clin Nutr. 2010;29:50711. [CrossRef]

5. Kuyumcu ME, Yeşil Y, Oztürk ZA, et al. Challenges in nutritional evaluation of hospi-talized elderly; Always with mini-nutritional assessment? Eur Geriatr Med. 2013;4:231-6. [CrossRef]

6. Saka B, Kaya O, Ozturk GB, Erten N, Karan MA. Malnutrition in the elderly and its rela-tionship with other geriatric syndromes. Clin Nutr. 2010;29:745-8. [CrossRef]

7. Tasci I, Safer U, Naharci MI. Multiple antihyperglycemic drug use is associated with undernutrition among older adults with type 2 diabetes mellitus: a cross-sectional study. Diabetes Ther. 2019;10:1005-18. [CrossRef]

8. Savas S, Saka B, Akın S, et al. The prevalence and risk factors for urinary incontinence among inpatients, a multicenter study from Turkey. Arch Gerontol Geriatr. 2020;90:104-22. [CrossRef]

9. Bolayir B, Arik G, Yeşil Y, et al. Validation of nutritional risk screening-2002 in a hospitalized adult population. Nutr Clin Pract. 2019;34:297-303. [CrossRef]

10. Yildirim ZG, Uzunlulu M, Caklili OT, Mutlu HH, Oguz A. Malnutrition rate among hos-pitalized patients with type 2 diabetes mellitus. Prog Nutr. 2018;20:183-8. [CrossRef]

11. Evert AB, Dennison M, Gardner CD, et al. Nutrition therapy for adults with diabe-tes or prediabetes: a consensus report. Diabetes Care. 2019:42:731-54. [CrossRef]

12. Drewnowski A, Warren-Mears VA. Does aging change nutrition requirements? J Nutr Health Aging. 2001;5:70-4.

13. Brownie $S$. Why are elderly individuals at risk of nutritional deficiency? Int J Nurs Pract. 2006;12:110-8. [CrossRef]

14. Kuhlmann MK, Kribben A, Wittwer M, Hörl WH. OPTAmalnutrition in chronic renal failure. Nephrol Dial Transplant. 2007;22:13-9. [CrossRef]

15. Rizvi AA. Nutritional challenges in the elderly with diabetes. Int J Diabetes Mellit. 2009;1:26-31. [CrossRef]

16. Guigoz Y, Lauque S, Vellas BJ. Identifying the elderly at risk for malnutrition the mini nutritional assessment. Clin Geriatr Med. 2002;18:737-57. [CrossRef]

17. Vanderwee K, Clays E, Bocquaert I, Gobert M, Folens B, Defloor T. Malnutrition and associated factors in elderly hospital patients: A Belgian cross-sectional, multi-centre study. Clin Nutr. 2010;29:469-76. [CrossRef]

18. Adler NE, Ostrove JM. Socioeconomic status and health: what we know and what we don't. Ann N Y Acad Sci. 
1999;896:3-15. [CrossRef]

19. Yusuf S, Joseph P, Rangarajan S, et al. Modifiable risk factors, cardiovascular disease, and mortality in 155 722 individuals from 21 high-income, middle-income, and low-income countries (PURE): a prospective cohort study. Lancet. 2019;395:795-808. [CrossRef]

20. Long AN, Dagogo-Jack S. Comorbidities of diabetes and hypertension: mechanisms and ap-proach to target organ protection. J Clin Hypertens. 2011;13:244-51. [CrossRef]
21. Gæde P, Lund-Andersen H, Parving HH, Pedersen O. Effect of a multifactorial interven-tion on mortality in type 2 diabetes. N Engl J Med. 2008;358:580-91. [CrossRef]

22. Neelemaat F, Kruizenga HM, de Vet HC, Seidell JC, Butterman M, van Bokhorst-de van der Schueren MA. Screening malnutrition in hospital outpatients. Can the SNAQ malnutrition screening tool also be applied to this population? Clin Nutr. 2008;27:439-46. [CrossRef] 